\title{
100 Years after von Dungern \& Hirschfeld: Kinship Investigation from Blood Groups to SNPs
}

\author{
Peter Bugert Harald Klüter \\ Institute of Transfusion Medicine and Immunology, Medical Faculty Mannheim, Heidelberg University; \\ German Red Cross Blood Service Baden-Württemberg - Hessen; Mannheim, Germany
}

This issue of Transfusion Medicine and Hemotherapy is dedicated to the pioneers in immunohematology and forensic genetics and in particular to the Polish physician and immunologist Ludwig Hirschfeld (fig. 1). Born August 5, 1884 in Warsaw, he died March 7, 1954 in Wrocław. From 1907 to 1911 Hirschfeld worked at the Heidelberg Institute for Experimental Cancer Research together with Emil von Dungern. In 1910 they published their fundamental work on the inheritance of ABO blood groups [1] that is recognized as a milestone in human genetics and the onset of forensic genetics.

In the 20th century the progress of forensic genetics was mostly affected by the introduction of the inheritance of the $\mathrm{ABO}$ and further blood group systems and later by genetic polymorphisms of serum proteins, leukocyte antigens (HLA), and erythrocyte enzymes. The era of anonymous DNA markers, i.e. the tandem repetitive DNA regions (minisatellites), was heralded in 1985 when Sir Alec Jeffreys and collegues [2] presented the DNA fingerprinting technique. Enormous progress was then achieved when PCR-based analysis of short tandem repeats (STRs) was introduced in the early 1990s. The history of forensic genetics and the use of the different genetic marker systems in kinship analysis are reviewed by Geserick and Wirth [3] in this issue Transfusion Medicine and HEMOTHERAPY.

Since DNA sequence analysis of different genomes was intensified, researchers became aware of diallelic markers that represent the most abundant genetic variation evenly spread in the genome. These single nucleotide polymorphisms (SNPs) and short insertion-deletion polymorphisms (indels) are the basis of current developments in forensic genetics that are summarized in the article by Schneider [4]. The diallelic marker systems and their use in trace and kinship analysis is also the topic of the original research articles in this issue. One option could be the typing of non-anonymous SNPs with a clear genotype-phenotype correlation such as SNPs in the
Fig. 1. Ludwig Hirschfeld (Ludwik Hirszfeld; from $h t t p: / /$ zlotemysli.w.interia. $\mathrm{pl} /$ sentencje/h_/ hirszfeld.html)

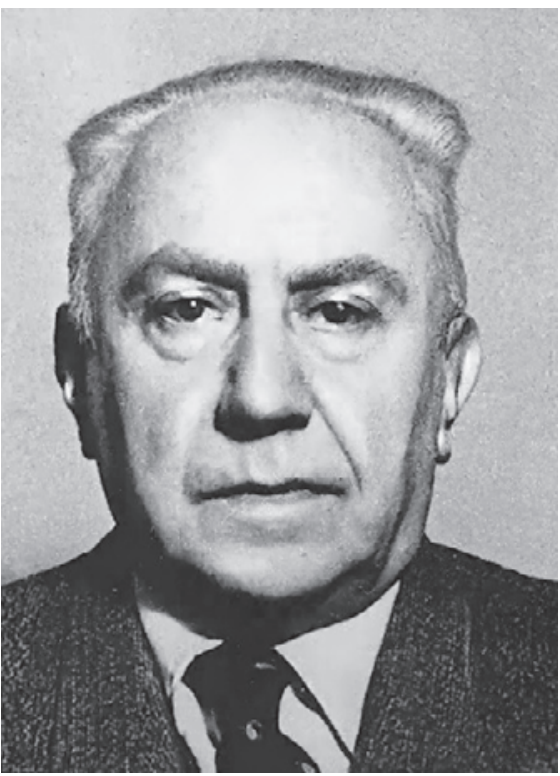

$A B O$ gene representing the molecular basis of the $\mathrm{ABO}$ blood groups [5]. A larger panel of anonymous autosomal SNPs, the 49 SNPforID SNPs, is already used in different laboratories. Experiences are presented by the groups of Schwark et al. [6] and Børsting et al. [7]. Furthermore, Phillips et al. [8] report about the application of both the SNPforID panel and high-density SNP arrays including about 1.8 million SNP and indel markers. The current progress of introducing diallelic markers to forensic genetics is amended by the work of Pena and Pena [9] who describe a powerful and low-cost method for typing of 40 indels with a widespread chromosomal location.

Over the past 100 years forensic genetics including kinship analysis has developed from phenotyping of blood groups and other blood cell markers to genotyping of anonymous DNA markers. This progress was mostly driven by the significantly

\section{KARGER \\ Fax +497614520714 \\ Information@Karger.de}

www.karger.com (c) 2012 S. Karger GmbH, Freiburg

$1660-3796 / 12 / 0393-0161 \$ 38.00 / 0$

Accessible online at:

www.karger.com/tml
Prof. Dr. rer. nat. Peter Bugert

Institut für Transfusionsmedizin und Immunologie

DRK-Blutspendedienst Baden-Württemberg - Hessen

Friedrich-Ebert-Straße 107, D-68167 Mannheim, Germany

Tel. +49 621 370694-95, Fax -96

peter.bugert@medma.uni-heidelberg.de 
higher power of exclusion for the DNA markers, especially the highly polymorphic STRs. However, STR-based analysis is hampered by the relatively high mutation rate of the markers. This is one of the driving forces for the development and introduction of DNA fingerprints based on the much more stable diallelic markers. All together, these achievements led to the current status of paternity testing with clear and convincing evidence due to highly informative genetic systems.

\section{References}

1 von Dungern E, Hirschfeld L: Ueber Vererbung gruppenspezifischer Strukturen des Blutes. Z Immunforsch 1910;6:284-292.

2 Jeffreys AJ, Wilson V, Thein SL: Hypervariable 'minisatellite' region in human DNA. Nature 1985; 314:67-73.

$>3$ Geserick G, Wirth I: Genetic kinship investigation from blood groups to DNA markers. Transfus Med Hemother 2012;39(3):163-175.

4 Schneider PM: Beyond STRs: The role of diallelic markers in forensic genetics. Transfus Med Hemother 2011;39(3):176-180.
5 Bugert P, Rink G, Kemp K, Klüter H: Blood group $\mathrm{ABO}$ genotyping in paternity testing. Transfus Med Hemother 2011;39(3):182-186.

6 Schwark T, Meyer P, Harder M, Modrow JH, von Wurmb-Schwark N: The SNPforID assay as a supplementary method in kinship and trace analysis. Transfus Med Hemother 2011;39(3):187-193.

7 Børsting C, Mikkelsen M, Morling N: Kinship analysis with diallelic SNPs - Experiences with the SNPforID multiplex in an ISO17025 accreditated laboratory. Transfus Med Hemother 2011;39(3): 195-201.
8 Phillips C, García-Magariños M, Salas A, Carracedo Á, Lareu MV: SNPs as supplements in simple kinship analysis or as core markers in distant pairwise relationship tests: when do SNPs add value or replace well-established and powerful STR tests? Transfus Med Hemother 2011;39(3): 202-210.

9 Pena HB, Pena SDJ: Automated genotyping of a highly informative panel of 40 short insertion-deletion polymorphisms resolved in polyacrylamide gels for forensic identification and kinship analysis. Transfus Med Hemother 2011;39(3):211-216. 